\title{
COMPARATIVE ANALYSIS OF WIRE DRAWING PROCESSES WITH THE USE OF MONOLITHIC AND ROLLER DIES
}

\author{
ANALIZA PORÓWNAWCZA PROCESÓW CIĄGNIENIA DRUTÓW \\ Z ZASTOSOWANIEM CIĄGADEE MONOLITYCZNYCH I ROLKOWYCH
}

The paper presents a comparative analysis of wire drawing with the use of monolithic and roller dies on the basis of numerical simulations performed using the QForm $3 D$ program. Significant differences between the above types of drawing dies in the aspect of round wire technology are presented. Distributions of stresses and strains on the semi-finished cross-section during drawing and the final product were analysed in particular. $\mathrm{Nu}$ merical simulations were performed for the low-carbon unalloyed C1OD steel. The calculations concerned the production of wires with a diameter of $6.5 \mathrm{~mm}$ from a wire rod with a diameter of $8.5 \mathrm{~mm}$. The results of simulations and analyses showed the validity of using roller dies in the aspect of widely understood production profitability and process efficiency, dependent on tool and energy consumption and time consumption, while maintaining the guarantee of obtaining the required surface quality, shape and internal quality.

Keywords: drawing, wire, roller die, monolithic die
W artykule przeprowadzono analizę porównawcza ciagnienia drutów w ciagadtach monolitycznych i rolkowych na podstawie symulacji numerycznych wykonanych za pomoca programu QForm 3D. Przedstawiono istotne różnice pomiędzy wro. rodzajami ciagadet w aspekcie technologii wytwarzania drutów okragtych. Analizie poddano w szczególności rozktady naprężeń $i$ odkształceń na przekroju pótwyrobu w trakcie ciagnienia $i$ wyrobu końcowego. Symulacje numeryczne wykonano dla stali niskowęglowej niestopowej w gatunku C1OD. Obliczenia dotyczyty roytwarzania drutów o średnicy 6,5 $\mathrm{mm}$ z walcówki o średnicy $8,5 \mathrm{~mm}$. Wyniki symulacji i analiz wykazaty zasadność stosowania ciagadet rolkowych w aspekcie szeroko rozumianej optacalności produkcji i wydajności procesu, zależnych od zużycia narzędzi $i$ energii oraz czasochtonności, przy zachowaniu grarancji uzyskania wymaganej jakości powierzchni, ksztattu i jakości wewnętrznej.

Stowa kluczowe: ciagnienie, drut, ciagadto rolkowe, ciagadto monolityczne

\section{INTRODUCTION}

Fencing systems, consisting primarily of gratings, are one of the most developing segments of the steel products market for general use. Gratings are made of low-carbon steel wires connected by spot welding, which are suitable for galvanising [1-6]. The same applies to wire strength - the large range of acceptable $\mathrm{C}$ and $\mathrm{Mn}$ contents gives the possibility to regulate the required wire rod properties in a wide range $[7,8]$. The wires for panels and grates with diameters ranging from $2-3 \mathrm{~mm}$ to $6.5-7.5 \mathrm{~mm}$ are usually drawn with the use of monolithic dies. However, due to greater efficiency, some fence system manufacturers decide to use roller dies [9].

A typical monolithic die consists of two mutually connected parts - a hole made of a material capable of transferring very high pressures and ensuring a highly smooth surface, and a metal frame that protects the hole against damage and facilitates the attachment of the die in the seat of the drawing machine. In roller dies, the deformation area is formed by 2 to 6 non-driven rollers that rotate as a result of friction against the surface of the drawn material. Roller dies

Corresponding Author: marek.burdek@imz.pl are widely used for drawing shaped products with complex cross-sections, but they are also used for drawing wires with a circular cross-section.

Roller dies have a number of advantages, which include:

- drawing force lower than in the monolithic die,

- the possibility of using large partial reductions, which results in a smaller number of draws,

- the possibility of using higher drawing rates,

- the possibility of obtaining products with cyclically changing cross-section and products with a shaped surface (e.g. ribbed reinforcing bars),

- reduction of time consumption and production costs,

- the possibility of conducting the drawing process without grease or a lubricant carrier,

- roller die structure, which allows mounting in every wire and rod drawing machine,

- easy grinding and polishing of working rollers.

It should be emphasised, however, that roller dies are less rigid than monolithic dies. As a result, it is more difficult to achieve such narrow dimensional tolerances as in conventional (monolithic) dies.

The properties of products drawn with roller dies differ slightly from conventional drawing:

- most often there are slightly lower strength properties and better plastic properties, 
- lower residual stresses are observed,

- there is less heterogeneity of deformation.

The industrial use of roller dies has resulted in a number of favourable phenomena of technical and economic importance. A clear reduction in drawing costs was observed, which was caused, among others, by:

- lower energy consumption,

- decrease in the number of heat treatment procedures,

- elimination of lubricant carriers and expensive greases,

- lower tool consumption.

Roller die rolls do not require frequent regeneration and are characterised by considerable durability.

Considering the above advantages, some manufacturers of wires for fence gratings - mainly due to higher efficiency - decided to use roller dies in their drawing lines.

The purpose of the paper is to compare the process of drawing round wires with the use of a monolithic die and a roller die from the point of view of stress and strain distribution using numerical simulation performed in the Qform3D program.

\section{SAMPLE MATERIAL}

The sample material is C10D steel in accordance with [5]. The test programme includes obtaining a $\phi 6.5 \mathrm{~mm}$ wire from a $\phi 8.5 \mathrm{~mm}$ wire rod in two draws (Tab. 1 ).

\begin{tabular}{|c|c|c|c|c|c|}
\hline $\begin{array}{c}\text { Draw } \\
\text { No. }\end{array}$ & $\begin{array}{c}\text { Initial } \\
\text { diameter } \\
\mathbf{m m}\end{array}$ & $\begin{array}{c}\text { Final } \\
\text { diameter } \\
\mathbf{m m}\end{array}$ & $\begin{array}{c}\text { Cross- } \\
\text { section } \\
\text { loss } \\
\%\end{array}$ & $\begin{array}{c}\text { Total } \\
\text { cross- } \\
\text { section } \\
\text { loss } \\
\%\end{array}$ & $\begin{array}{c}\text { Drawing } \\
\text { rate } \\
\mathbf{m} / \mathbf{s}\end{array}$ \\
\hline 1 & 8.5 & 7.25 & 26.0 & 26.2 & 4 \\
\hline 2 & 7.25 & 6.5 & 18.4 & 41.5 & 5 \\
\hline
\end{tabular}

Drawing is carried out with the use of monolithic dies and roller dies placed in rolling cassettes in two sets of 3 rolls (Fig. 1) [9]. The first set of rollers is used for initial deformation and the second set of rollers is used for final deformation. An outline of drawing with roller dies is presented in Fig. 2 and 3 [9].

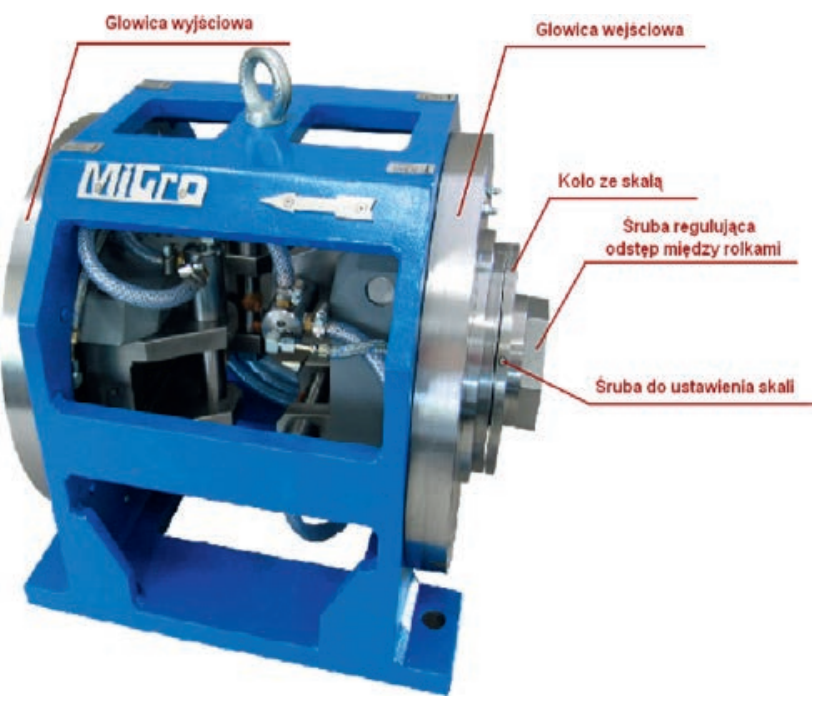

Fig. 1. Cassette for mounting sets of rollers [9] Rys. 1. Kaseta do montażu zestawów rolek [9]

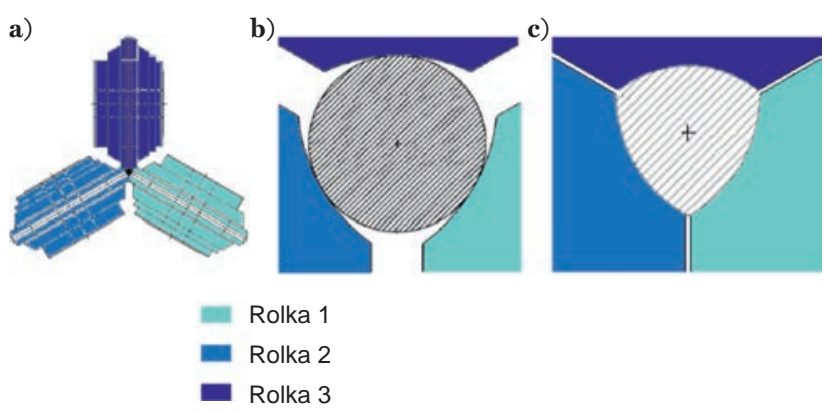

Fig. 2. Deformation of the wire in roughing rollers: a) rollers; b) position of rollers during the wire introduction; c) wire profile after deformation in rollers [9]

Rys. 2. Odkształcanie drutu w rolkach wstępnych: a) widok rolek; b) układ rolek przy wprowadzaniu drutu; c) profil drutu po odkształceniu w rolkach wstępnych [9]
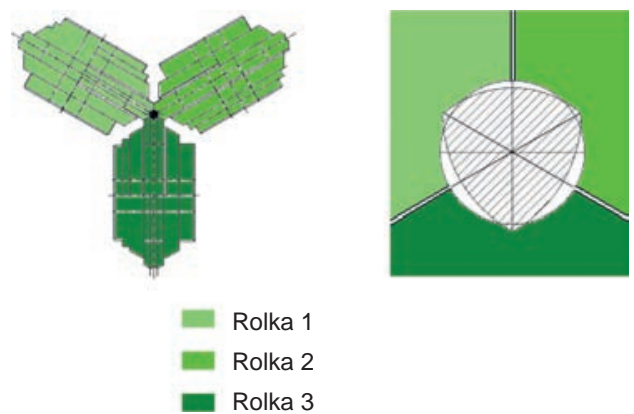

Fig. 3. Deformation of the wire in finishing rollers: a) rollers, b) wire profile after deformation in roughing rollers together with a profile view of the deformed wire in finishing rolls introduced into the roughing rollers [9]

Rys. 3. Odkształcanie drutu w rolkach na gotowo: a) widok rolek, b) profil rolek na gotowo $\mathrm{z}$ kształtem drutu po odkształceniu w rolkach wstępnych [9]

\section{SIMULATION BOUNDARY CONDITIONS}

The numerical simulations were carried out with the use of the Qform3D v8.4 program. An elastic-plastic model was used; the steel hardening curve was selected from the Qform3D base. Fig. 4 shows an example of a spatial view of tools used for drawing with a roller die.

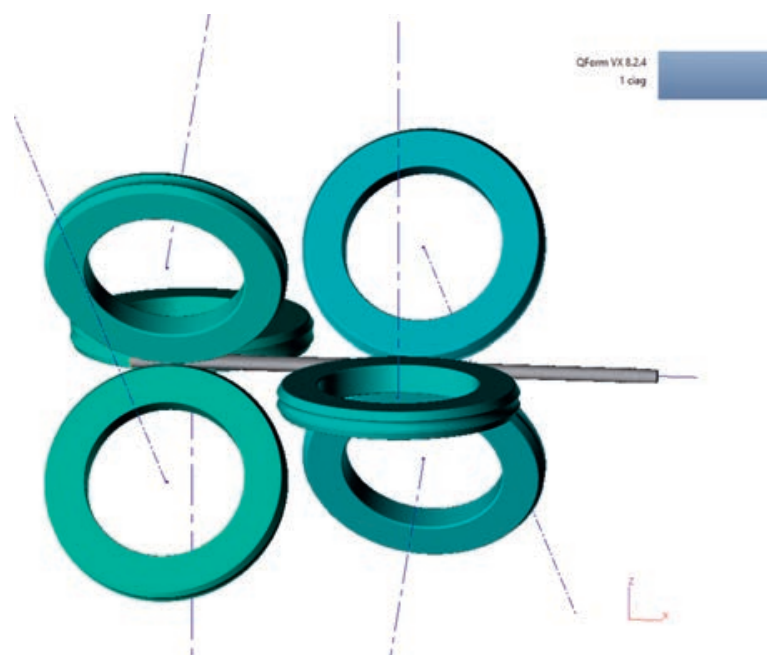

Fig. 4. Roller position for drawing through a roller die in the Qform3D program

Rys. 4. Układ rolek przy ciągnieniu przez ciągadło rolkowe w programie Qform3D 


\section{RESULTS OF NUMERICAL SIMULATIONS}

\subsection{DEFORMATION DISTRIBUTION}

Fig. 5 presents strain distributions on the longitudinal section of the wire during drawing in the 1st and 2nd draw, and Fig. 6 - strain distributions on the cross section of the wire after the 1st and 2 nd draw for both drawing variants. It shows that the deformation distributions in both drawing methods are similar - values of approx. $\varepsilon=0.30-0.32$ inside the rod and $\varepsilon=0.40-0.45$ in the outer layers (1st draw), and $\varepsilon=0.61-0.65$ and $\varepsilon=0.75-0.79$ (2nd draw) respectively. Several percent higher deformations were found when drawing with a monolithic die than in the roll drawing operation.

\subsection{DISTRIBUTION OF EFFECTIVE STRESS}

Fig. 7 presents stress intensity distributions for both drawing variants. It was found that drawing with a monolithic die introduces much higher stress into the drawn wire than in the case of roller drawing. It should be remembered that roller drawing was carried out each time by 2 sets of rollers (the sum of partial deformations) and this may be the reason for reducing the intensity of stress.

\section{SUMMARY}

The paper presents the results of numerical simulations of drawing a $\phi 6.5 \mathrm{~mm}$ wire through a monolithic and roller die. Both methods are used for manufacturing wires for fencing grates. Monolithic dies are used when high quality wires are necessary (surface without defects, no ovality, small dimensional deviations). However, drawing with the use of roller dies has its advantages, which include, first of all, greater efficiency and lesser sensitivity to contamination and surface defects in wires.

The numerical analysis of drawing processes showed that both drawing methods generally do not affect the size and distribution of deformations on the wire cross section. It was also found that drawing with a monolithic die introduces much higher stress into the drawn wire than in the case of roller drawing.
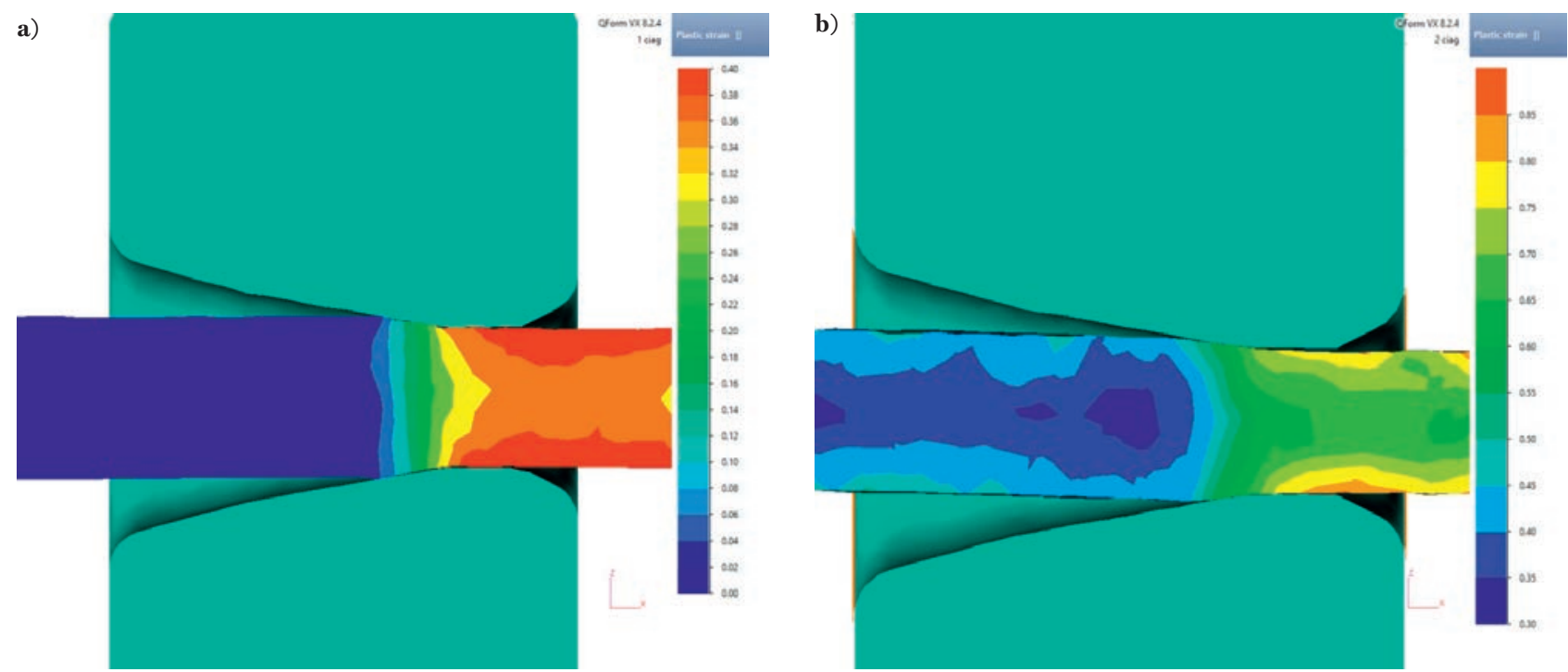

c)

d)
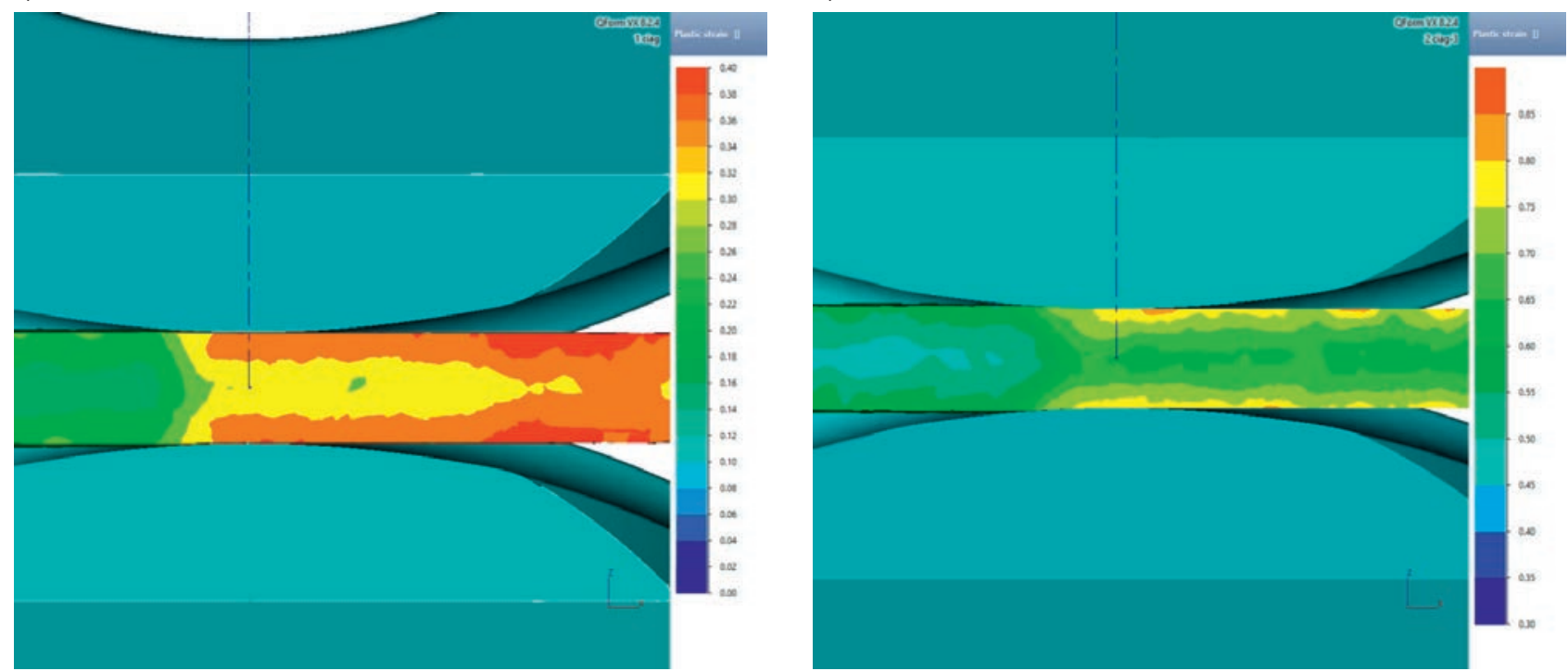

Fig. 5. Distribution of strain on longitudinal section of the wire in the first (a, c) and second (b, d) draw during drawing through a monolithic $(\mathbf{a}, \mathbf{b})$ and roller $(\mathbf{c}, \mathbf{d})$ die

Rys. 5. Rozkład odkształcenia na przekroju wzdłużnym drutu w ciągach pierwszym (a, c) i drugim (b, d) podczas ciągnienia przez ciągadło monolityczne $(a, b)$ i rolkowe $(\mathbf{c}, \mathbf{d})$ 
a)

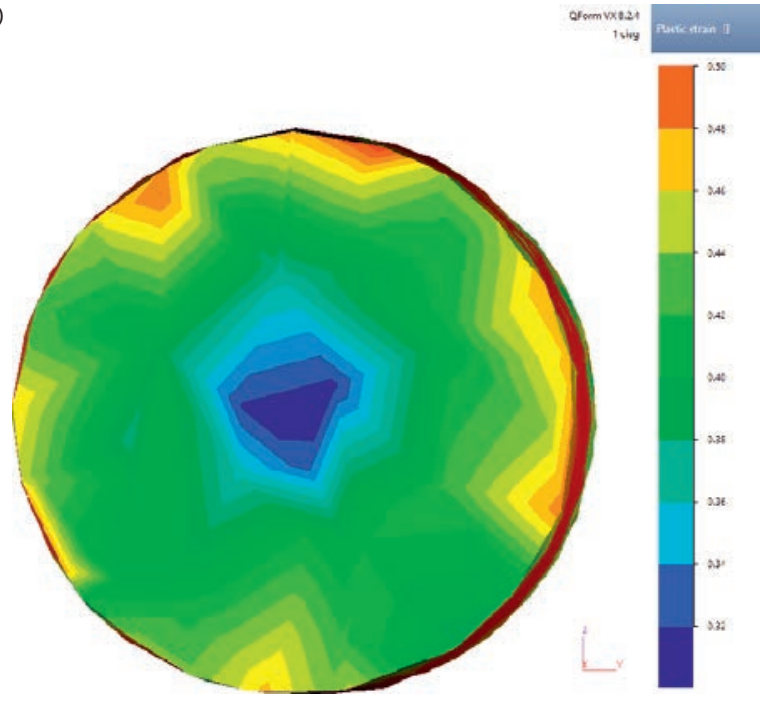

c)

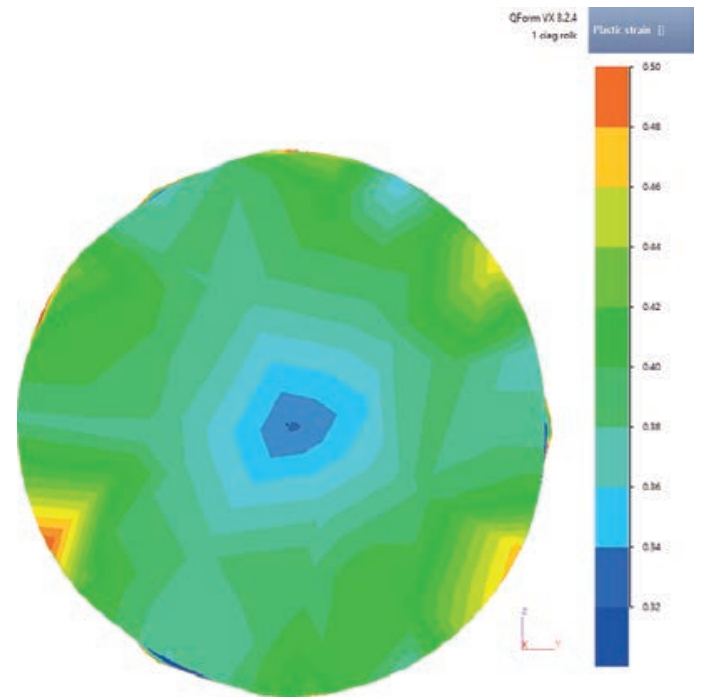

b)

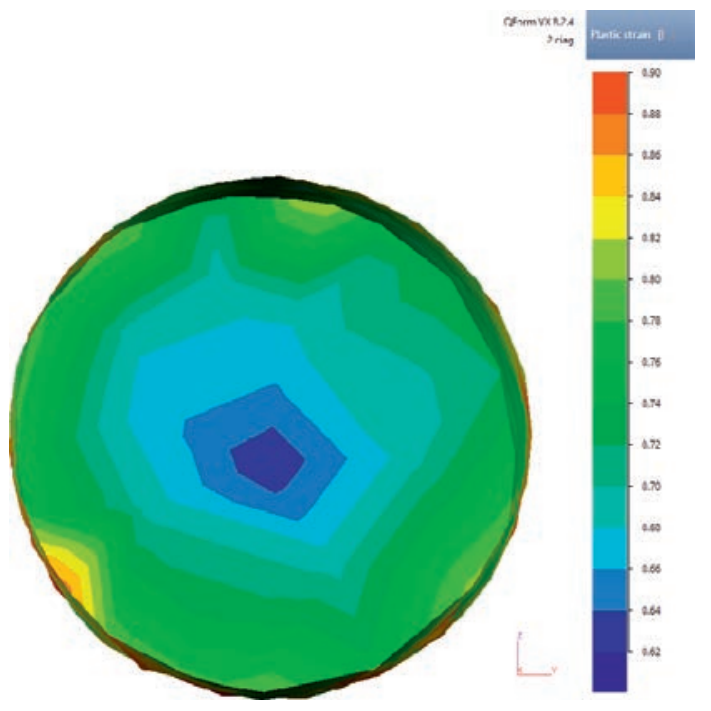

d)

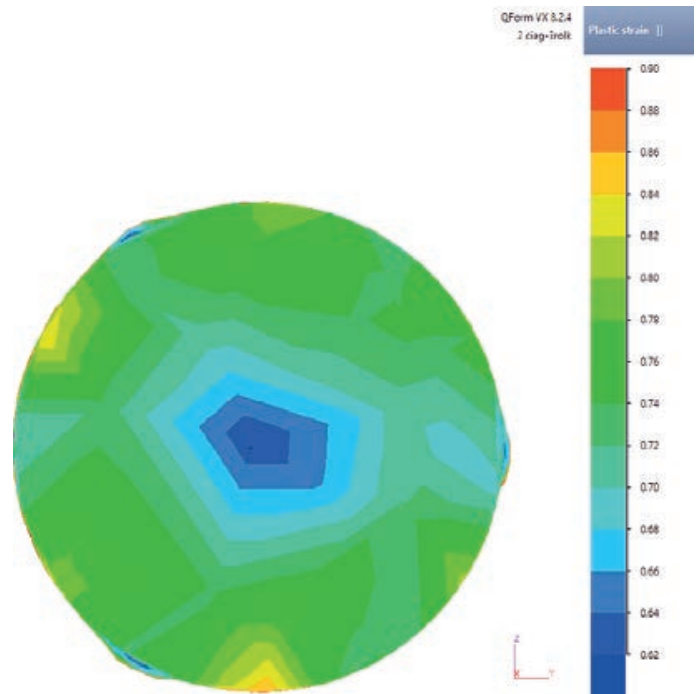

Fig. 6. Distribution of strain on the wire's cross-section in the first (a, c) and second (b, d) draw during drawing through a monolithic (a, b) and roller $(\mathrm{c}, \mathrm{d})$ die

Rys. 6. Rozkład odkształcenia na przekroju poprzecznym drutu w ciągu pierwszym (a, c) i drugim (b, d), po ciągnieniu przez ciągadło monolityczne $(a, b)$ i rolkowe $(\mathbf{c}, d)$

a)

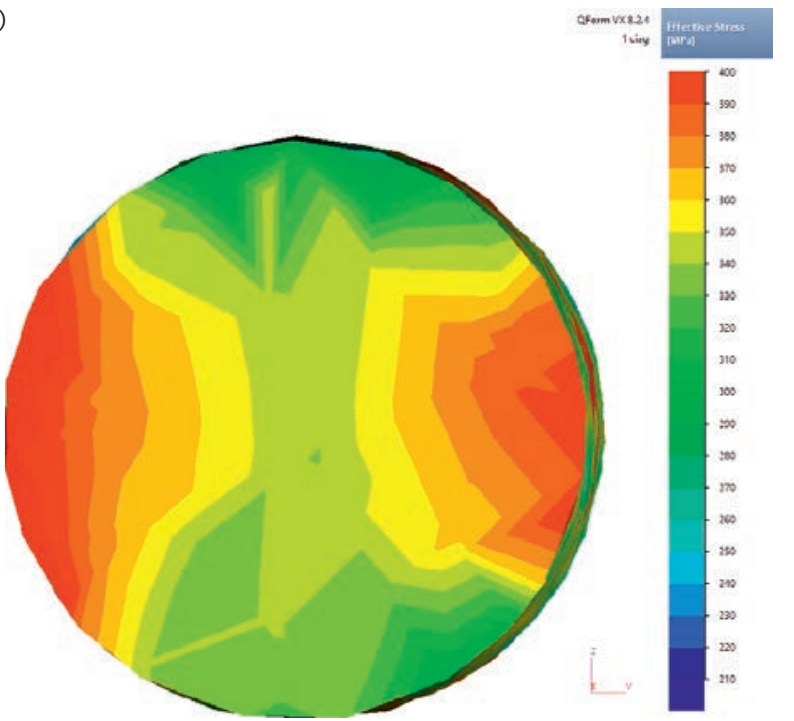

b)

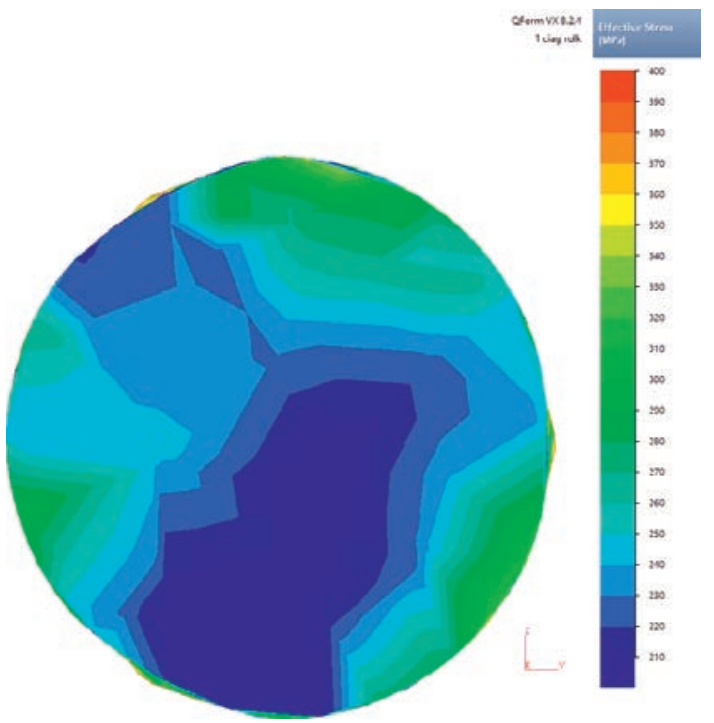

Fig. 7. Distribution of effective stress on wire cross-section in the first (a, c) and second (b, d) draw during drawing with the use of monolithic $(\mathbf{a}, \mathbf{b})$ and roller $(\mathbf{c}, \mathrm{d})$ dies

Rys. 7. Rozkład intensywności naprężeń na przekroju poprzecznym drutu w ciągu pierwszym (a,c) i drugim (b,d), po ciągnieniu przez ciągadło monolityczne $(a, b)$ i rolkowe $(c, d)$ 
c)

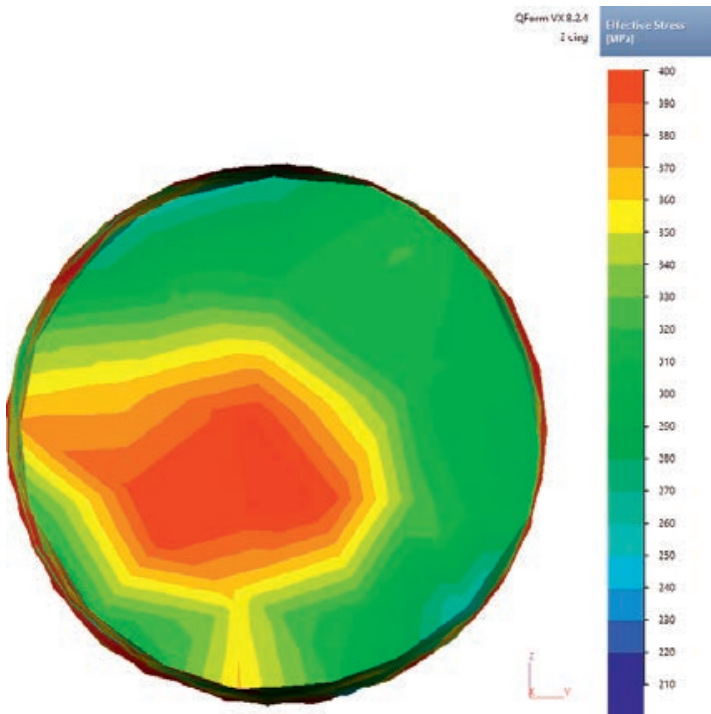

d)

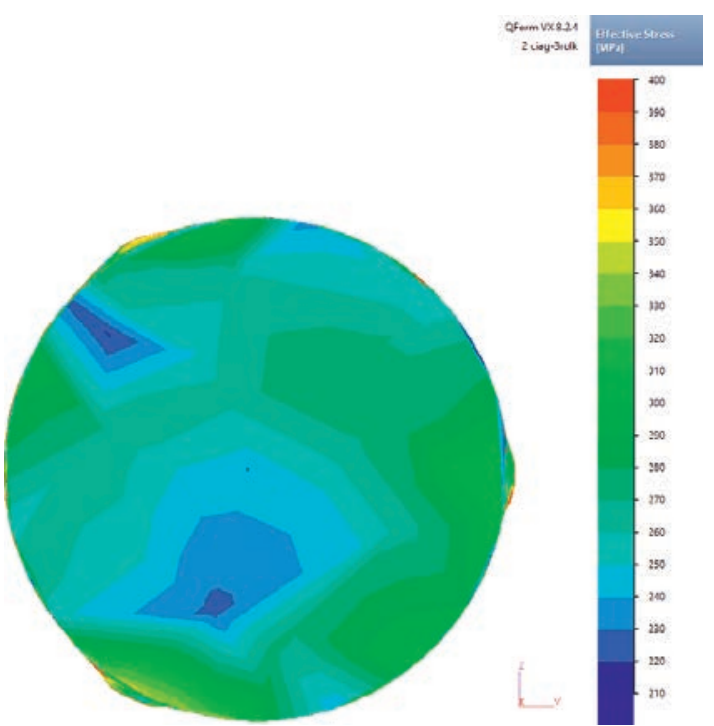

Fig. 7 cont. Distribution of effective stress on wire cross-section in the first $(a, c)$ and second $(b, d)$ draw during drawing with the use of monolithic $(\mathbf{a}, \mathbf{b})$ and roller $(\mathbf{c}, \mathbf{d})$ dies

Rys. 7 cd. Rozkład intensywności naprężeń na przekroju poprzecznym drutu w ciągu pierwszym (a,c) i drugim (b,d), po ciągnieniu przez ciągadło monolityczne $(\mathbf{a}, \mathbf{b})$ i rolkowe $(\mathbf{c}, \mathbf{d})$

\section{REFERENCES}

[1] Polski Komitet Normalizacyjny. PN-EN 10223-4:2013-05. Drut stalowy $i$ royroby z drutu na ogrodzenia. Częśś 4: Siatka ogrodzeniowa z drutu stalowego z potaczeniami zgrzewanymi. Warszawa: PKN, 2013.

[2] Polski Komitet Normalizacyjny. PN-EN 10223-7: 2013-05. Drut stalowy $i$ wyroby z drutu na ogrodzenia. Część 7: Panele zgrzewane z drutu stalowego na ogrodzenia. Warszawa: PKN, 2013.

[3] Polski Komitet Normalizacyjny. PN-EN 10025-2: 2007. Wyroby walcowane na goraco ze stali konstrukcyjnych. Część 2: Warunki techniczne dostaroy stali konstrukcyjnych niestoporeych. Warszawa: PKN, 2007.

[4] American Society for Testing and Materials. ASTM A510/A510M: 2018. Standard Specification for General Requirements for Wire Rods and Coarse Round Wire, Carbon Steel, and Alloy Steel. 2018.

[5] Polski Komitet Normalizacyjny. PN-EN ISO 16120-2:2017-04: Walcórwk ze stali niestopowej przeznaczona do produkcji drutu. Część 2 . Wymagania dla walcóreki ogólnego przeznaczenia. Warszawa: PKN, 2017 .
[6] Polski Komitet Normalizacyjny. PN-EN 10025-1:2007: Wyroby walcowane na goraco ze stali konstrukcyjnych. Część 1: Ogólne warunki techniczne dostawy. Warszawa: PKN, 2007.

[7] Polski Komitet Normalizacyjny. PN-EN 10218-1:2012. Drut stalowy i wyroby z drutu. Postanowienia ogólne. Część 1: Metody badań. Warszawa: PKN, 2012.

[8] Polski Komitet Normalizacyjny. PN-EN 10218-2:2012. Drut stalowy i wyroby z drutu. Postanowienia ogólne. Wymiary i tolerancje wymiarów drutu. Warszawa: PKN, 2012.

[9] W. Szulc, M. Burdek, M. Popęda, R. Baliński, A. Witkowski. Uruchomienie nowej ciagarni drutu w firmie Legipol Sp. z o.o. Prace Instytutu Metalurgii Żelaza, 2016, 68 (1), p. 42-48. 